\title{
ECONOMIC EFFECTS OF BIRD FLU SPREADING IN THE ARAB REPUBLIC OF EGYPT
}

\author{
Soliman, Esam S. and Dalia F. Jab Allah* \\ Department of Agricultural Economics, Desert Research Center, El- \\ Matareya, Cairo, Egypt \\ *E-mail: dalia_farouk1973@yahoo.com
}

$\mathrm{T}$ here is no doubt that food no longer become commodities trading, according to the laws of supply and demand, but food issue became at the front of important issues to the State, because it is a strategy issue, which can not be left to contemporary global conditions and variables. Also, it is impossible to say that it will be safe, because food is a vital necessity and indispensable for human. Also local food production with appropriate amounts make stable life and community is turning for construction and development.

The poultry industry is one of the promising industries in Egypt, which enjoyed great support by government since its inception. State has issued several laws and resolutions supporting the industry and encouraging investment on it. It gave the producers the right to obtain supported feed and approving establishment of poultry projects on agricultural land, exempting some industrial projects from taxes for ten years from the date of construction, increasing the credit facilities, and protecting poultry industry totally by banning import of poultry in 1986. Then imposing high tariffs on poultry imports reached $80 \%$ in 1997. About feed industry and the most important of is yellow corn. These factors have pushed the process of investment in industry and their rings, where investment amount was 18-20 billion pounds in 2005, in addition to working capital, which amount to about 5 billion pounds a year, and providing about 1.5 million permanent jobs, and nearly a million temporary jobs. Poultry meat, red meat and fish are at the forefront of animal proteins group, which include the strategies of food security in Egypt in general, and as a result of the production of poultry meat more efficient in terms of conversion efficiency, as the conversion rate reached to 2.3: 1 i.e. $2.3 \mathrm{~kg}$ of feed given $1 \mathrm{~kg}$ of poultry meat. As for red meat production, the conversion rate is $7: 1$, i.e. $7 \mathrm{~kg}$ of feed given 1 
$\mathrm{kg}$ of red meat, in addition to that, the production of poultry is a source of low costs protein in Egypt compared to other sources. The total consumption of poultry in Egypt is about 987 thousand tons in 2008, 829 thousand tons from it are fattening chickens, which represent about $84 \%$ of the total consumption of poultry in Egypt and 158 thousand tons of local chicken meat, ducks, geese, turkeys and rabbits. The industry consists of a set of interrelated production chains, starting with a schedule and ending with broilers production, egg production, poultry industry, and some relating industries like poultry feed production plants and massacres. Broilers production farms is the most important stage of the poultry industry and widespread in republic governorates, where the other stages of industry depend on it, and the total number of broilers farms in 2008 is about 25.95 thousands farms on the republic and total maximum capacity is 1.62551 billion chickens per year and it has been shown that about $72.7 \%$ of poultry production is concentrated in five major governorate, Qaliubiya, Sharqiya, Gharbia, Dakahlia and Behera at the rates of about 30.8, 16.2, $11.4,9.2$ and $5.1 \%$, respectively.

Keywords: bird flu, poultry industry, average gross margin, rate of return, food security, production, consumption, North Sinai

Bird flu is contagious viral disease affecting most species of birds. It has been recognized as a disease since 1878, and the most serious type is that known as H5N1, which has the ability to transfer from birds to humans and water, playing an important role in the transmission and dissemination of influenza between birds and the infect (Ibrahim, 2007). It is transforming also by the tools used in breeding, nutrition, transportation, feed, persons working on farms. Disease symptoms in birds are loss of appetite, sharp decline in egg production, emergence of eggs without shell, secretions of mucous in the nose, drooling out of the beak and feathers wrinkle and break. The percentage of sudden death is about $100 \%$. Its symptoms in humans are headache, chills, muscle aches, dry cough and inflammation of eye conjunctiva and in severe cases it is fatal. In June 2007, it was reported about 100 cases of human infection with virus in the world, although this figure does not represent risk in the number for other deadly diseases to humans, but the ability of influenza viruses to transform easily caused the scientists fear that virus H5N1 could spread easily from person to person. Therefore, the lack of preventive vaccine for humans from infection with the virus commercially increases the risk of disease. Infection of avian influenza virus transfer to humans if he contact with sick chickens in unsterile environment. The virus come out from the body of a bird in their wastes, Egyptian J. Desert Res., 62/63, 71-86 (2012/2013) 
which turns into a powder carried by the air. Virus can survive for long periods between 15-35 days in bird droppings, especially in low temperatures, but all the poultry meats does not transfer the virus to humans. The chicken should be cooked on high temperature and in a good way. Pig is a more candidate animal to work as a mediator, where in its tissue avian influenza virus transform into harmful mutation to humans. Therefore, the disease was found spread among the people in the areas of pig farms adjacent to chicken farms. Import vaccine from other countries may not be effective in reducing the spread of the disease, where virus type that infected a country may be different from other countries, because of the rapid evolution of viruses and their unceasing mutations. Each State has been proven that it has infection cases, shall start to separate the virus and produce a serum against it.

The most important protection from this disease is to wash hands with warm water and soap frequently to prevent infection. Many countries have taken precautions to prevent infection, most countries import frozen birds in fear of possible transformation of the virus due to contamination of packaging equipment.

It has been announced outbreak of bird flu in Egypt in the seventeenth of February 2006, that was in three governorates only and it has expanded to 19 governorates, which negatively reflected on livestock husbandry in Egypt (Sawalhi, 2005). Consumers get away from buying birds and poultry, and most of the farms and birds shops were closed. Infection reached to a high level in Sharqua, Qalyubia, Behera and Giza Governorates, where 1000 chickens were executed in Sharqua in the early infection in Egypt, and about 40 thousand birds in Qalyubia, and all infected birds in Giza Governorate were executed and the infected focus was cleaned (Fatima Shafik, 2006).

According to WHO statistics, data in table (1 in annexes), show that Egypt did not have human cases of Avian Influenza before 2006, while the cases of infection and death from the disease were about 51.23 cases during the period 2006-2008, so Egypt occupied the second rank in the world during that period, after Indonesia with relative importance about 20.7 and $13.5 \%$, respectively. While Egypt occupied the first rank for infection cases and death in 2009, of about 71.1 and $33.3 \%$, respectively. In spite of disease restrictions in many countries of the world, Egypt has occupied the third rank for the average number of infected cases and death of human, because of Avian Influenza during the period 2003-2009, with percentage about 18.0 and $10.3 \%$ of average infected cases and death worldwide, respectively. Predicting the risk requires efforts consolidation to reduce economic and health damages of this disease (Mohamed, 2007).

The average per capita from chicken meat in Egypt is still relatively low, compared to many countries around the world, where average per capita of chicken meat in Egypt is $9 \mathrm{~kg}$ per year in 2008, while it is up to $11.9 \mathrm{~kg}$ in 
the world, $20.9 \mathrm{~kg}$ in the European Union, $50.2 \mathrm{~kg}$ in the United States, 35.6 $\mathrm{kg}$ in Saudi Arabia and $64.8 \mathrm{~kg}$ in the UAE.

The research problem is represented on emergence of bird flu and its spread in Egypt in general and consequences of this crisis in North Sinai Governorate in particular, which caused some of the negative effects on economic variables associated with the poultry industry, which affect the size of investments in this industry as well as their impact on the economics of poultry production and its role in the agricultural and national economy (Samour, 2006 and Al Shatalh and Ali, 2008). This requires identifying the causes of that problem for the policy and decision makers in this area.

The research aims to identify the current status of production and consumption of white meat in Egypt, as well as the current situation for the production of poultry in North Sinai Governorate, as well as to identify the economic impacts of bird flu in some of economic and technical variables of farmers under study areas and the economics of fattening chickens in the farms in North Sinai.

\section{MATERIALS AND METHODS}

The research depends on published and unpublished secondary data collected from the relevant official bodies, such as the Ministry of Agriculture and Land Reclamation, Presidency of Cabinet Center for Information and Decision Support (2007 and 2008), and the Central Agency for Public Mobilization and Statistics, as well as a number of researches and studies. That is in addition to the data mentioned in questionnaire forms, which has been prepared for this purpose and it has been applied on a random sample of poultry farms in North Sinai Governorate during 2010. Search also adopted the methods of descriptive and quantitative statistics in data analysis to extract some of the indicators and criteria to measure the impact of avian influenza on the economics of the poultry industry in North Sinai Governorate.

\section{RESULTS AND DISCUSSION}

\section{Current Status of the White Meat in Egypt}

Data in table (1) refer to the increase in local production of poultry meat of about 46.24 thousand tons per year with increase rate of $7.11 \%$ of annual average, which amounted to about 0.65 million tons during the period 1990-2008. The local consumption of white meat also increased by about 31.10 thousand tons, with increase in rate of $4.47 \%$ of average annual domestic consumption, which amounted to about 0.7 million tons. While the value of poultry meat has increased by 506.3 million pounds with annual

Egyptian J. Desert Res., 62/63, 71-86 (2012/2013) 
increase percentage of $4.88 \%$ of the average value of poultry meat, which amounted to about 10.37 billion pounds per annum because of the increase in average price of poultry by about 0.38 pounds, with an annual increase percentage of about $6.32 \%$ of average price during the study period.

Results also indicate that the amount of the annual increase in average per capita of white meat was about $0.31 \mathrm{~kg}$, with annual increase percentage of $2.88 \%$ of average per capita during the period mentioned above, which amounted to about $10.76 \mathrm{~kg}$ per year. While the rate of selfsufficiency of white meat ranged from 120.50 to $46.84 \%$ in $1990-2002$, respectively, the average of annual increase was about $3.67 \%$ of the average rate of self-sufficiency during the period 1990-2008.

Table (1). Equations of general time trend of the evolution of both total production and consumption, average price, the value of white meat, the average per capita, the gap and the rate of selfsufficiency of the white meat in Egypt during the period 19902008 .

\begin{tabular}{|c|c|c|c|c|c|c|c|c|c|}
\hline \multirow{2}{*}{ Particulars } & \multirow{2}{*}{ Unit } & \multicolumn{2}{|c|}{$\alpha$} & \multicolumn{2}{|c|}{$\beta$} & \multirow{2}{*}{$\mathbf{R}^{2}$} & \multirow{2}{*}{$\mathbf{F}$} & \multirow{2}{*}{ Average } & \multirow{2}{*}{$\begin{array}{c}\text { Annual } \\
\text { rate of } \\
\text { change } \\
(\%)\end{array}$} \\
\hline & & Value & $\mathbf{T}$ & Value & $\mathbf{T}$ & & & & \\
\hline Local production & $\begin{array}{c}\text { thousand } \\
\text { ton }\end{array}$ & 187.54 & $2.77 * *$ & 46.24 & $7.78^{* *}$ & 0.78 & $60.47 * *$ & 0.65 & 7.11 \\
\hline Local consumption & $\begin{array}{l}\text { thousand } \\
\text { ton }\end{array}$ & 384.28 & $8.19 * *$ & 31.10 & $7.56^{* *}$ & 0.77 & $57.14 * *$ & 0.70 & 4.47 \\
\hline Farm average price & Pound/kg & 2.22 & $4.00 * *$ & 0.38 & $7.77 * *$ & 0.78 & $60.45^{* *}$ & 6.01 & 6.32 \\
\hline Poultry meat value & $\begin{array}{l}\text { million } \\
\text { pound }\end{array}$ & 732.50 & $2.12 *$ & 506.30 & $16.50 * *$ & 0.94 & $272.22^{* *}$ & 10.37 & 4.88 \\
\hline Per capita & $\mathrm{kg} /$ year & 7.62 & $10.84 * *$ & 0.31 & $5.10 * *$ & 0.60 & $25.98 * *$ & 10.76 & 2.88 \\
\hline Self-sufficiency rate & $\%$ & 60.11 & $5.98 * *$ & 3.07 & $3.48 * *$ & 0.42 & $* * 1 Y . \wedge$ & 83.57 & 3.67 \\
\hline
\end{tabular}

Source: collected and calculated from data in table (1) in annex.

\section{The Current Situation of Poultry Production in North Sinai Governorate}

Data in table (2) show increasing local poultry production in North Sinai Governorate by about 0.09 thousand tons per year with increase rate of about $5.52 \%$ of the annual average, which amounted to 1.63 thousand tons in the period 1991-2009. Increasing in the value of poultry meat was shown to be about 1.09 million pounds by annual increase of about $10.70 \%$ of the average value of poultry meat, which amounted to about 10.19 million pounds per year. This may be attributed to the increase in the average price of poultry by about 0.24 pounds with annual increase rate of about $4.43 \%$ of the average price during the study period. 
Table (2). The equations of general time trend of the evolution of total production, value of the white meat, and the average price of white meat in the governorate of North Sinai, during the period 1991-2009.

\begin{tabular}{|c|c|c|c|c|c|c|c|c|c|}
\hline \multirow{2}{*}{ Particulars } & \multirow{2}{*}{ Unit } & \multicolumn{2}{|c|}{$\alpha$} & \multicolumn{2}{|c|}{$\beta$} & \multirow{2}{*}{$\mathbf{R 2}$} & \multirow{2}{*}{$\mathbf{F}$} & \multirow{2}{*}{ Average } & \multirow{2}{*}{$\begin{array}{c}\text { Annual } \\
\text { rate of } \\
\text { change } \\
(\%)\end{array}$} \\
\hline & & Value & $\mathbf{T}$ & Value & $\mathbf{T}$ & & & & \\
\hline $\begin{array}{l}\text { Poultry } \\
\text { production }\end{array}$ & $\begin{array}{c}\text { Thousan } \\
\text { d ton }\end{array}$ & 0.73 & $2.29 *$ & 0.09 & $3.24 * *$ & 0.38 & $10.51 * *$ & 1.63 & 5.52 \\
\hline $\begin{array}{l}\text { Average } \\
\text { price }\end{array}$ & $\begin{array}{c}\text { Pound/ } \\
\text { kg }\end{array}$ & 3.05 & $3.77 * *$ & 0.24 & $3.31 * *$ & 0.39 & $10.96 * *$ & 5.41 & 4.43 \\
\hline $\begin{array}{l}\text { Poultry } \\
\text { meat value }\end{array}$ & $\begin{array}{l}\text { Million } \\
\text { pound }\end{array}$ & 0.75 & 0.19 & 1.09 & $3.19 * *$ & 0.37 & $10.19 * *$ & 10.19 & 10.70 \\
\hline $\begin{array}{l}\text { General } \\
\text { farm }\end{array}$ & Farm & 10.72 & 0.51 & 11.59 & $6.31 * *$ & 0.70 & $39.79 * *$ & 1.50 & 11.04 \\
\hline full farm & Farm & 68.75 & $3.58^{*}$ & 12.66 & $5.41 * *$ & 0.63 & $29.31 * *$ & 195 & 6.49 \\
\hline
\end{tabular}

Data in table (3 in annexes) show fluctuation in the number of working farms, as they ranged between 30 and 265, in 1997 and 2009, which represent about 30.00 and $77.94 \%$, respectively. While the relative importance of working farms and total farms ranged between 18.45 and 95.77\%, during the period 1991 and 1998, respectively. When estimating the directional relationship between working farms and the total farms, as shown in table (2), it is an increasing as a general trend, reached to about 12.13 farms annually, at changing rate of about 11.04 and $6.49 \%$, respectively.

Table (3). Production of poultry in some centers in the governorate of North Sinai, during the months of 2009.

\begin{tabular}{|c|c|c|c|c|c|c|c|c|c|c|c|c|c|c|}
\hline \multirow{2}{*}{ Centers } & \multicolumn{12}{|c|}{ Months } & \multirow{2}{*}{ Total } & \multirow{2}{*}{$\%$} \\
\hline & Jan. & Feb. & March & April & May & June & July & Aug. & Sept. & Oct. & Nov. & Dec. & & \\
\hline Arish & 1000 & 0.00 & 4800 & 0.00 & 0.00 & 16000 & 3000 & 0.00 & 0.00 & 0.00 & 6650 & 0.00 & 31450 & 1.74 \\
\hline $\begin{array}{l}\text { Sheikh } \\
\text { Zuwaid }\end{array}$ & 74445 & 3870 & 3660 & 11620 & 15500 & 0.00 & 0.00 & 5800 & 0.00 & 0.00 & 19000 & 5500 & 72395 & 4.01 \\
\hline Bir al-Abed & 97000 & 101000 & 102000 & 97000 & 145500 & 140500 & 213000 & 210500 & 191000 & 146000 & 157800 & 99000 & 1700300 & 94.19 \\
\hline Rafah & 1000 & 0.00 & 0.00 & 0.00 & 0.00 & 0.00 & 0.00 & 0.00 & 0.00 & 0.00 & 0.00 & 0.00 & 1000 & 0.06 \\
\hline Total number & 106445 & 106445 & 110460 & 108620 & 161000 & 156500 & 216000 & 216300 & 191000 & 146000 & 183450 & 104500 & 1805145 & 100.00 \\
\hline$\%$ & 5.90 & 5.81 & 6.12 & 6.02 & 8.92 & 8.67 & 11.97 & 10.58 & 8.09 & 10.16 & 10.79 & 5.79 & 100. & 00 \\
\hline
\end{tabular}

Data in table (3) show the relative importance of poultry production in North Sinai Governorate, according to the centers during the months of the year 2009. It was found that Bir Al-Abed center is in the first rank for the total number of chickens by 1.7 million chickens representing about $94.19 \%$ of the total number of chickens in the governorate, which was estimated as 1.81 million chickens in 2009, followed by Sheikh Zuwaid center, El Arish

Egyptian J. Desert Res., 62/63, 71-86 (2012/2013) 
and Rafah by $4.01,1.74$ and $0.06 \%$, respectively, of total number of chickens in governorate during the same year, while it was found that May, June, July, August, September, October and November months are the most prolific months in production rate by $70.37 \%$ of the total number of chickens in months during the year 2009. This refers to the importance of providing veterinary care during those months.

\section{The General Features of the Poultry Industry in North Sinai Governorate}

Data in table (4 in annex) show that the total number of farms in North Sinai Governorate is 246 farms and the production capacity of fattening poultry farms was 9696 chickens with rates of 0.95 and $0.60 \%$, respectively, relative to the total records of the country in 2010, while there is no massacres at this province. That refers to the need to establish massacres in governorate fitted with and the number of fatting chickens.

\section{The Economic Effects of the Bird Flu in Sample Farms}

To find out the effects of bird flu crisis on poultry production in North Sinai Governorate, the impact of this crisis on many technical and economic variables was measured and compared, during the crisis in 2006 and before 2005. Then the change rate was calculated for each, after overcoming this crisis in 2009 and comparing it with the crisis situation in 2006, to define the current and future status of poultry production in North Sinai Governorate. Table (4) reveals decrease in all the economic variables under study in North Sinai Governorate during 2006 than it was in 2005, except feed price. The price of chickens has achieved greater rates of decline between variables under study by $66.67 \%$ than it was before the crisis. The average number of sold chickens, the number of permanent employment, average sale price, the number of dead chickens, the number of chickens, the average worker's wage, the amount of feed used where all decreased by $62.83,50,46.67,42.86,21.43,14.29$ and $13.04 \%$, respectively, comparing to 2005 , while average sale was affected by the crisis and decreased by $6.25 \%$. More than half of the chickens were disposed before completion of the growth cycle in order to reduce the costs of feeding and care. So, the staying of chicken in farm makes the product more expensive than the expected revenue from the sale at session completion, because of the low average of selling price by $53 \%$ of what it was in 2005 , which made producers dispose $51 \%$ from chicken farm, although the rate of dead chickens was limited by $5 \%$ of the total school and there is no death case due to bird flu. This indicates that the governorate of North Sinai was not directly affected by bird flu, but it was affected by the manner of crisis management in 2006 . 
Table (4). The economic effects of bird flu on poultry industry in farms under study before, during and after the crisis in North Sinai Governorate.

\begin{tabular}{|c|c|c|c|c|c|c|c|}
\hline \multirow[t]{2}{*}{ Particulars } & \multirow[t]{2}{*}{ Unit } & \multirow{2}{*}{$\begin{array}{c}\begin{array}{c}\text { Before } \\
\text { disease in } \\
2005\end{array} \\
\text { Average }\end{array}$} & \multicolumn{2}{|c|}{ During disease in 2006} & \multicolumn{2}{|c|}{ After disease in 2009} & \multirow{2}{*}{$\begin{array}{c}\begin{array}{c}\text { Comparing } \\
\text { situation } \\
\text { after } \\
\text { disease }\end{array} \\
\%^{(3)}\end{array}$} \\
\hline & & & Average & $\%^{(1)}$ & Average & $\%^{(2)}$ & \\
\hline The number of chickens & Chicken & 7000 & 5500 & -21.43 & 7000 & 27.27 & 0 \\
\hline Purchase price of the chicken & Pound & 0.9 & 0.3 & -66.67 & 5 & 1566.67 & 455.56 \\
\hline The amount of feed used & Ton & 23 & 20 & -13.04 & 24 & 20.00 & 4.35 \\
\hline Price per ton of feed & Pound & 750 & 950 & 26.67 & 2020 & 112.63 & 169.33 \\
\hline $\begin{array}{l}\text { The number of permanent } \\
\text { employment }\end{array}$ & Worker & 2 & 1 & -50.00 & 2 & 100.00 & 0.00 \\
\hline Average wage of the worker & Pound & 700 & 600 & -14.29 & 750 & 25.00 & 7.14 \\
\hline $\begin{array}{l}\text { The number of temporary } \\
\text { employment }\end{array}$ & Worker & 1 & 1 & 0.00 & 1 & 0.00 & 0.00 \\
\hline Average wage of the worker & Pound & 200 & 200 & 0.00 & 300 & 50.00 & 50.00 \\
\hline The number of dead chickens & Chicken & 490 & 280 & -42.86 & 380 & -48.65 & -22.45 \\
\hline The number of disposed chicken & Chicken & 0 & 2800 & 0 & 0 & - & - \\
\hline The number of sold chickens & Chicken & 6510 & 2420 & -62.83 & 6620 & 237.76 & 1.69 \\
\hline Average sale weight & $\mathrm{kg}$ & 1.6 & 1.5 & -6.25 & 1.8 & 20.00 & 12.50 \\
\hline Average sale price & Pound / kg & 7.5 & 4 & -46.67 & 11 & 175.00 & 46.67 \\
\hline
\end{tabular}

Source: calculated from the date of questionnaire form 2010

The previous table show significant improvement of all variables under study in 2009 than it was in 2006, where number of chickens, price of chicken, amount of used feed, price of feed per ton, number of permanent employment, average wage of worker, number of sold chicken, average weight of a chicken, average sale weight, and average selling price have increased by 27.27, 1566.67, 20, 112.63, 100, 25, 50, 237.76, 20 and 175\%, respectively. And when comparing the situation for these variables in 2009 with that before the crisis 2005 , the study shows significant improvement for all economic variables under study.

\section{The Economic Effects of Bird Flu on the Economics of Chickens Fattening}

The results in table (5) refer to the economics of chickens fattening in North Sinai Governorate including all costs of feeding, total return, economic efficiency indicators and productivity of fattening. 
Table (5). The rate of return costs in farms under study before, during and after the crisis in North Sinai Governorate.

\begin{tabular}{|c|c|c|c|c|c|c|}
\hline \multirow{2}{*}{ Particulars } & \multirow{2}{*}{$\begin{array}{c}\begin{array}{c}\text { Before disease } \\
\text { in } 2005\end{array} \\
\text { Average }\end{array}$} & \multicolumn{2}{|c|}{ During disease in 2006} & \multicolumn{2}{|c|}{ After disease in 2009} & \multirow{2}{*}{$\begin{array}{c}\begin{array}{c}\text { Comparison after } \\
\text { disease }\end{array} \\
\%(3)\end{array}$} \\
\hline & & Average & $\%(1)$ & Average & $\%(2)$ & \\
\hline Purchasing chickens cost & 6300 & 1650 & -73.81 & 35000 & 2021.21 & 455.56 \\
\hline Purchase costs of feed & 17250 & 19000 & 10.14 & 48480 & 155.16 & 181.04 \\
\hline Labor cost & 1600 & 800 & -50.00 & 1800 & 125.00 & 12.50 \\
\hline Drug cost & 1050 & 1500 & 42.86 & 1050 & -30.00 & 0.00 \\
\hline Bedding cost & 1600 & 1450 & -9.38 & 1600 & 10.34 & 0.00 \\
\hline Energy cost & 1000 & 900 & -10.00 & 1000 & 11.11 & 0.00 \\
\hline Equipment cost & 150 & 200 & 33.33 & 170 & -15.00 & 13.33 \\
\hline Total variable cost & 28950 & 25500 & -11.92 & 89100 & 249.41 & 207.77 \\
\hline Fixed cost (rent) & 1500 & 1500 & 0.00 & 1500 & 0.00 & 0.00 \\
\hline Total cost & 30450 & 27000 & -11.33 & 90600 & 235.56 & 197.54 \\
\hline Return of main product & 78120 & 14520 & -81.41 & 131067 & 802.73 & 67.79 \\
\hline Return of secondary product & 1250 & 650 & -48.00 & 1400 & 115.38 & 12.00 \\
\hline Total Revenue & 79390 & 15170 & -80.89 & 132476 & 773.28 & 66.91 \\
\hline Net return & 48290 & 11830 & $75.82-$ & 41876 & 253.98 & -14.40 \\
\hline Gross margin & 50420 & 10330 & -79.51 & 43376 & 319.90 & -13.97 \\
\hline Return of the cost & 2.61 & 0.56 & -78.44 & 1.46 & 160.71 & -43.90 \\
\hline
\end{tabular}

The results indicate that the overall costs of chickens fattening including variable costs are associated with the size of production such as purchase of chickens, nutrition, permanent and temporary employment, medicines, disinfectants, accessories of bedding and heating, and finally the costs of equipment, and other fixed costs like farm rent. The results in table (5) indicate that the total variable costs decreased by $11.92 \%$ during the crisis in 2006, compared to the situation before the crisis in 2005, and this decrease has reached maximum for the cost of purchasing chickens, where the amount of decrease was about $73.81 \%$ and less for bedding, while the drug and equipment cost has increased by 42.86 and $33.33 \%$, respectively. The same table shows that the total variable costs has increased by $249.41 \%$ after the crisis in 2009, comparing to the situation during the crisis in 2006. This increase has reached the maximum for the cost of purchasing chickens by about $2021.21 \%$, and minimum for the cost of bedding by $10.34 \%$, while the cost of drugs and equipment had decreased by 30 and 15\%, respectively. Comparing the situation of these variables in 2009 and before the crisis in 2005 show that the total variable costs has increased by $207.77 \%$, while the height has reached the maximum for the cost of buying chickens by $455.56 \%$.

Studying the terms of the fixed costs, in farms under study in North Sinai Governorate, the previous table shows that the total fixed costs did not 
change before, during and after the crisis, considering the fixed costs (rent) are burden upon farm owner whether produced or stop production.

Studying the terms of total revenue in farms under study in North Sinai Governorate (Table 5), it became clear that the total overall revenue has decreased by $80.89 \%$ during the crisis in 2006, comparing to the situation before the crisis in 2005 . Also, it increased by $773.28 \%$ after the crisis in 2009 comparing to the situation during the crisis in 2006. When comparing the situation of this variable in 2009 and before the crisis in 2005, it was shown that it increased also by an amount of $66.91 \%$

By extrapolating the results of table (5), which describe some indicators of the economic efficiency of chicken fattening in farms (net revenue, gross margin and rate of return of the cost), it was found that net average returns in farms of North Sinai Governorate decreased by $75.82 \%$ during the crisis in 2006 comparing to the situation before the crisis in 2005 . It increased by $253.98 \%$ after the crisis in 2009 , comparing to the situation during the crisis in 2006. Comparing the situation of this variable in 2009 with that before the crisis in 2005 show that it decreased by $14.40 \%$, and this can be attributed to increase the cost of purchase chickens and feed than it was before the crisis.

Total average margin in farms of North Sinai Governorate decreased by $79.51 \%$ during the crisis in 2006 , comparing the situation before the crisis of 2005 . Total average margin increased by $319.90 \%$ after the crisis in 2009 , comparing the situation during the crisis of 2006. Comparing the situation for this variable in 2009 and before the crisis in 2005, shows that it has decreased by $13.97 \%$, and this was due to increase variable costs by $207.77 \%$ from that in 2005 .

Regarding to the proportion of return and costs of farms in North Sinai Governorate, it is clear that it decreased by $78.44 \%$ during the crisis in 2006, comparing to the situation before the crisis in 2005. Also, it increased by $160.71 \%$ after the crisis in 2009 , comparing to the situation during the crisis in 2006. When comparing the situation for this variable in 2009 and before the crisis in 2005, it shows that it decreased by $43.90 \%$, and this is due to increase in total cost of about $197.54 \%$ from that before the crisis in 2005.

\section{The Indicators of Marketing Efficiency}

Table (6) refers to marketing efficiency indicators, which include marketing differences and marketing efficiency. To know the impact of disease spreading on those indicators, period before disease and after spread the disease have been compared.

Egyptian J. Desert Res., 62/63, 71-86 (2012/2013) 
Table (6). Indicators of efficiency marketing of poultry farms of field study in North Sinai Governorate before, during and after bird flu.

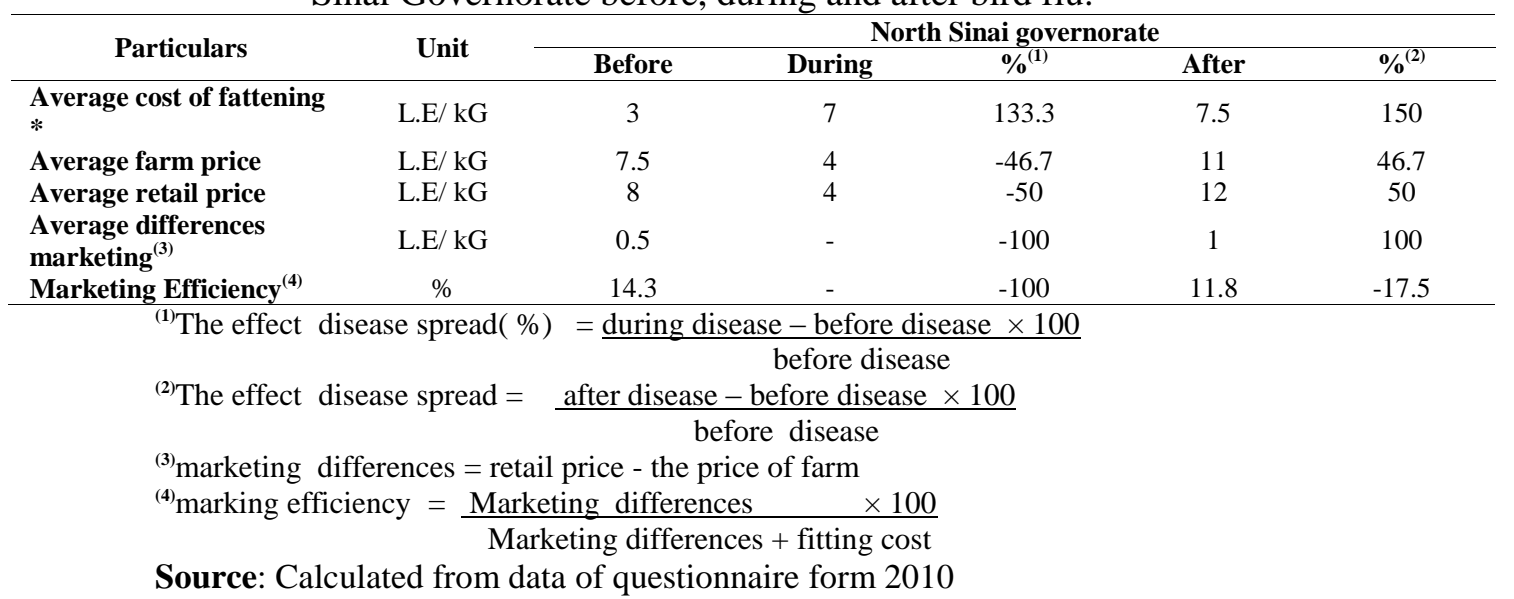

It was shown that the implications of bird flu crisis in Egypt in general and the North Sinai Governorate in particular have led to a deterioration and a decrease in marketing differences of and marketing efficient by $100 \%$ for each of them. That is due to lack of difference between the average of price farm and the average of retail price and this along with high average cost of kilogram fattening compared to farm prices and retail prices, but during the post-crisis period. There has been improvement in marketing differences about $100 \%$, which may be attributed to higher retail prices than farm prices. While the deterioration of marketing efficiency standard but lesser than level during the crisis as decrease rate was $17.5 \%$. From obtained data, it was clear that the amount of imbalance in marketing indicators of fattening poultry, whether during the period of disease spread or later, increased at farm and consumer level to compensate the losses caused by the spread of disease.

\section{CONCLUSION}

Studying the economic effects of bird flu and its implications on the poultry industry in North Sinai Governorate, showed a decrease of all the economic variables under study and so in 2006 than it was in 2005, except the price of feed. Also, a significant improvement in all variables under study was shown in 2009 than it was in 2006. There was an increase in the number of chickens, the price of chicken, the amount of feed used, the price per ton of feed, the number of permanent labor, the average permanent and temporary worker's wages, the number of chicken sold, the average weight of a chicken, and the average selling price. When comparing the situation to 
those variables in 2009 than it was before the crisis in 2005, the study showed a significant improvement in all the economic variables under study.

Studying the indicators of economic efficiency of fattening chicken in farms under study showed reduction in both average net earnings, average gross margin, and the rate of return for the costs of farms in North Sinai Governorate during the crisis in 2006, compared to the situation before the crisis in 2005 . When it became clear, there was an improvement in these indicators after the crisis in 2009, compared to the situation during the crisis in 2006.

\section{RECOMMENDATIONS} following:

In the light of the foregoing data, the study recommends the 1. Using the scientific method and be calm and cautious during the crises, especially by the officials and the media, where the wrong decisions and advertising have a significant role in increasing the size of the losses.

2. The need for a comprehensive inventory of all poultry farms in the governorate of North Sinai and licensing it to be controlled in the case of the disease if it appears.

3. Determining an appropriate financial compensation by the government and that should be given to the owners of farms in the event of infection, to cover production costs, at least so do not give the opportunity to hide infection cases, fearing of the state might execute all birds.

4. Using geographic information systems in calculating poultry farms all over the country to illustrate the productive activities of industry in integrated database.

\section{REFERENCES}

Al Shatalh H.S.A. and S.A. Ali (2008). The economic effects of bird flu to the poultry industry in Egypt, a case study in Sharkia and Qaliubiya Governorate. The Thirty Three International Conference of Statistics, Computer Science and Applications, Cairo, 6 - 17 April 2008.

Fatima A. Shafik (2006). An economic study of the current status of the poultry industry in Egypt in light of the bird flu crisis. Egyptian Journal of Agricultural Economics, 16(4).

Ibrahim, H.I. (2007). Analytical study of chicken fattening industry (case study in Ismailia and Sharkia Governorates). The $15^{\text {th }}$ Conference of Agricultural Economists, Livestock in the Context of Egypt Agricultural Development, October 2007.

Mohamed A.A. (2007). An analytical study of the risks which face fattening poultry activities and means of treat them in Qalubia

Egyptian J. Desert Res., 62/63, 71-86 (2012/2013) 
Governorate. The $15^{\text {th }}$ Conference of Agricultural Economists, livestock in the Context of Egypt Agricultural Development, October 2007.

North Sinai Governorate, the Directorate of Agriculture in El- Arish, unpublished data, February 2010.

North Sinai Governorate (2010). The directorate of veterinary in El-Arish, unpublished secondary data.

Presidency of Cabinet Center for Information and Decision Support (2007). The study of the economic impacts of an outbreak of bird flu in Egypt.

Presidency of Cabinet Center for Information and Decision Support. A statistical report on the numbers and the production capacities of poultry farms and cooling refrigerators, January 2008.

Samour, H.M. (2006). The impact of the Spread of Bird Flu on the Economics of the Poultry Industry in Egypt (a case study in Sharkia Governorate). Egyptian Journal of Agricultural Economics, 6(4).

Sawalhi, H. (2005). Analyzing the structure of the poultry industry in Egypt, a proposed development in the light of the bird flu crisis, a proposal submitted to the Center for Information and Decision Support, cabinet. http://bird flu_sis.Gov.eg/ahtml/fluolool

http://www.who.int/csr/disease/avian_influenza 


\section{ANNEXES}

Table (1). Evolution of bird flu cases worldwide during the period 2003-2009.

\begin{tabular}{|c|c|c|c|c|c|c|c|c|c|c|c|c|c|c|c|c|}
\hline \multirow{3}{*}{ Items } & \multicolumn{4}{|c|}{$(2003-2005)$} & \multicolumn{4}{|c|}{$(2006-2008)$} & \multicolumn{4}{|c|}{ (2009) } & \multicolumn{4}{|c|}{ Total } \\
\hline & \multicolumn{2}{|c|}{ Cases } & \multicolumn{2}{|c|}{ Death } & \multicolumn{2}{|c|}{ Cases } & \multicolumn{2}{|c|}{ Death } & \multicolumn{2}{|c|}{ Cases } & \multicolumn{2}{|c|}{ Death } & \multicolumn{2}{|c|}{ Cases } & \multicolumn{2}{|c|}{ Death } \\
\hline & Number & $\% 1$ & Number & $\%$ & Number & $\%$ & Number & $\%$ & Number & $\% 1$ & Number & $\% 1$ & Number & $\% 1$ & Number & $\%$ \\
\hline Azerbaijan & 0 & 0.0 & 0 & 0.0 & 8 & 3.2 & 5 & 2.9 & 0 & 0.0 & 0 & 0.0 & 8 & 1.9 & 5 & 1.9 \\
\hline Bangladesh & 0 & 0.0 & 0 & 0.0 & 1 & 0.4 & 0 & 0.0 & 0 & 0.0 & 0 & 0.0 & 1 & 0.2 & 0 & 0.0 \\
\hline Cambodia & 4 & 2.7 & 4 & 5.1 & 4 & 1.6 & 3 & 1.8 & 0 & 0.0 & 0 & 0.0 & 8 & 1.9 & 7 & 2.7 \\
\hline China & 9 & 6.1 & 6 & 7.6 & 22 & 8.9 & 15 & 8.8 & 7 & 18.4 & 4 & 33.3 & 38 & 8.8 & 25 & 9.5 \\
\hline Djibouti & 0 & 0.0 & 0 & 0.0 & 1 & 0.4 & 0 & 0.0 & 0 & 0.0 & 0 & 0.0 & 1 & 0.2 & 0 & 0.0 \\
\hline Egypt & 0 & 0.0 & 0 & \begin{tabular}{|l|}
0.0 \\
\end{tabular} & 51 & 20.7 & 23 & 13.5 & 27 & 71.1 & 4 & 33.3 & 78 & 18.0 & 27 & 10.3 \\
\hline Indonesia & 20 & 13.5 & 13 & 16.5 & 121 & 49.0 & 102 & 59.7 & 0 & 0.0 & 0 & 0.0 & 141 & 32.6 & 115 & 43.9 \\
\hline $\begin{array}{l}\text { Iraq } \\
\text { Lao }\end{array}$ & 0 & 0.0 & 0 & 0.0 & 3 & 1.2 & 2 & 1.2 & 0 & 0.0 & 0 & 0.0 & 3 & 0.7 & 2 & 0.8 \\
\hline $\begin{array}{l}\text { People's } \\
\text { Democratic } \\
\text { Republic }\end{array}$ & 0 & 0.0 & 0 & 0.0 & 2 & 0.8 & 2 & 1.2 & 0 & 0.0 & 0 & 0.0 & 2 & 0.5 & 2 & 0.8 \\
\hline Myanmar & 0 & 0.0 & 0 & 0.0 & 1 & 0.4 & 0 & 0.0 & 0 & 0.0 & 0 & 0.0 & 1 & 0.2 & 0 & 0.0 \\
\hline Nigeria & 0 & 0.0 & 0 & 0.0 & 1 & 0.4 & 1 & 0.6 & 0 & 0.0 & 0 & 0.0 & 1 & 0.2 & 1 & 0.4 \\
\hline Pakistan & 0 & 0.0 & 0 & 0.0 & 3 & 1.2 & 1 & 0.6 & 0 & 0.0 & 0 & 0.0 & 3 & 0.7 & 1 & 0.4 \\
\hline Thailand & 22 & 14.9 & 14 & 17.7 & 3 & 1.2 & 3 & 1.8 & 0 & 0.0 & 0 & 0.0 & 25 & 5.8 & 17 & 6.5 \\
\hline Turkey & 0 & 0.0 & 0 & 0.0 & 12 & 4.9 & 4 & 2.3 & 0 & 0.0 & 0 & 0.0 & 12 & 2.8 & 4 & 1.5 \\
\hline Viet Nam & 93 & 62.8 & 42 & 53.2 & 14 & 5.7 & 10 & 5.9 & 4 & 10.5 & 4 & 33.3 & 111 & 25.6 & 56 & 21.4 \\
\hline Total & 148 & 100.0 & 79 & 100.0 & 247 & 100.0 & 171 & 100.0 & 38 & 100.0 & 12 & 100.0 & $\begin{array}{ll}433 & 1 \\
\end{array}$ & 100.0 & 262 & 100.0 \\
\hline
\end{tabular}

Table (2). Evolution of total production and consumption, average price of white meat, average per capita, hole and self -sufficiency rate of white meat in Egypt during the period 1990-2008.

\begin{tabular}{|c|c|c|c|c|c|c|c|}
\hline Particulars & $\begin{array}{c}\text { Production } \\
\text { (thousand ton) }\end{array}$ & $\begin{array}{c}\text { Consumption } \\
\text { (thousand ton) }\end{array}$ & $\begin{array}{c}\text { Average price of } \\
\text { poultry } \\
(\mathrm{LE} / \mathrm{kg})\end{array}$ & $\begin{array}{l}\text { Chicken meat } \\
\text { value (million } \\
\text { pound) }\end{array}$ & $\begin{array}{c}\text { Per capita } \\
\text { (kg/year) }\end{array}$ & $\begin{array}{c}\text { Hole } \\
\text { (thousand } \\
\text { ton) }\end{array}$ & $\begin{array}{c}\text { Self- } \\
\text { sufficiency } \\
(\%)\end{array}$ \\
\hline 1990 & 215 & 459 & 2.30 & 494.50 & 8.44 & -244 & 46.84 \\
\hline 1991 & 230 & 470 & 3.00 & 690.00 & 8.42 & -240 & 48.94 \\
\hline 1992 & 321 & 480 & 3.33 & 1068.93 & 8.51 & -159 & 66.88 \\
\hline 1993 & 328 & 549 & 4.77 & 1564.56 & 9.55 & -221 & 59.74 \\
\hline 1994 & 391 & 579 & 4.70 & 1837.70 & 9.83 & -188 & 67.53 \\
\hline 1995 & 480 & 606 & 5.42 & 2601.60 & 10.07 & -126 & 79.21 \\
\hline 1996 & 482 & 657 & 5.70 & 2747.40 & 10.70 & -175 & 73.36 \\
\hline 1997 & 506 & 685 & 5.93 & 3000.58 & 11.07 & -179 & 73.87 \\
\hline 1998 & 516 & 430 & 5.41 & 2791.56 & 6.91 & 86 & 120.00 \\
\hline 1999 & 629 & 524 & 5.40 & 3396.60 & 8.30 & 105 & 120.04 \\
\hline 2000 & 669 & 559 & 5.20 & 3478.80 & 8.64 & 110 & 119.68 \\
\hline 2001 & 863 & 721 & 5.17 & 4461.71 & 10.96 & 142 & 119.69 \\
\hline 2002 & 1164 & 966 & 5.38 & 6262.32 & 14.46 & 198 & 120.50 \\
\hline 2003 & 1047 & 878 & 6.12 & 6407.64 & 13.05 & 169 & 119.25 \\
\hline 2004 & 982 & 839 & 7.72 & 7581.04 & 12.18 & 143 & 117.04 \\
\hline 2005 & 1018 & 888 & 7.61 & 7746.98 & 12.69 & 130 & 114.64 \\
\hline 2006 & 895 & 936 & 9.03 & 7178.85 & 13.13 & -141 & 84.94 \\
\hline 2007 & 879 & 987 & 9.56 & 8403.24 & 13.77 & -108 & 89.06 \\
\hline 2008 & 834 & 987 & 12.44 & 10374.96 & 13.85 & -164 & 83.57 \\
\hline Average & 643.28 & 678.50 & 5.74 & 4320.47 & 10.76 & -45.37 & 90.78 \\
\hline
\end{tabular}

Source: collected and calculated from the data of the following:

- Food and Agriculture Organization (FAO), 2009.

- Ministry of Agriculture and Land Reclamation, Economic Affairs Sector, Central department of Agricultural Economics, records of Statistics Department, miscellaneous number.

Egyptian J. Desert Res., 62/63, 71-86 (2012/2013) 
Table (3). Evolution of total production quantity and value and average price of white meat in North Sinai Governorate during the period 1991- 2009.

\begin{tabular}{|c|c|c|c|c|c|c|}
\hline \multirow{3}{*}{ Particulars } & \multirow{3}{*}{$\begin{array}{c}\text { Production } \\
\text { (thousand } \\
\text { ton) }\end{array}$} & \multirow{3}{*}{$\begin{array}{l}\text { Average price of } \\
\text { poultry (LE/kg) }\end{array}$} & \multirow{3}{*}{$\begin{array}{c}\text { Chicken meat } \\
\text { value (million } \\
\text { pound) }\end{array}$} & \multicolumn{3}{|c|}{ Farms number } \\
\hline & & & & \multicolumn{2}{|c|}{ Working } & \multirow{2}{*}{ Total } \\
\hline & & & & Number & $\%$ & \\
\hline 1991 & 1.16 & 3.40 & 3.94 & 39 & 25.83 & 151 \\
\hline 1992 & 1.78 & 4.00 & 7.12 & 31 & 18.45 & 168 \\
\hline 1993 & 1.13 & 4.40 & 4.97 & 45 & 26.79 & 168 \\
\hline 1994 & 1.33 & 4.00 & 5.32 & 49 & 29.52 & 166 \\
\hline 1995 & 1.06 & 4.25 & 4.51 & 45 & 44.12 & 166 \\
\hline 1996 & 0.82 & 5.25 & 4.31 & 34 & 33.33 & 102 \\
\hline 1997 & 0.54 & 4.82 & 2.60 & 30 & 30.00 & 102 \\
\hline 1998 & 0.90 & 5.00 & 4.50 & 68 & 95.77 & 100 \\
\hline 1999 & 1.41 & 4.00 & 5.64 & 83 & 61.03 & 71 \\
\hline 2000 & 1.44 & 4.80 & 6.91 & 76 & 51.35 & 136 \\
\hline 2001 & 1.55 & 5.50 & 8.53 & 106 & 58.56 & 148 \\
\hline 2002 & 1.84 & 4.75 & 8.74 & 107 & 59.12 & 181 \\
\hline 2003 & 1.89 & 5.60 & 10.58 & 108 & 59.02 & 181 \\
\hline 2004 & 1.72 & 7.50 & 12.90 & 155 & 72.09 & 183 \\
\hline 2005 & 4.14 & $\wedge .00$ & 33.12 & 154 & 53.47 & 215 \\
\hline 2006 & 2.31 & 4.00 & 9.24 & 250 & 80.65 & 288 \\
\hline 2007 & 3.62 & 3.50 & 12.67 & 260 & 76.47 & 310 \\
\hline 2008 & 0.83 & 8.00 & 6.64 & 93 & 25.69 & 340 \\
\hline 2009 & 3.45 & 12.00 & 41.40 & 265 & 77.94 & 362 \\
\hline Average & 1.63 & 5.41 & 10.19 & 105 & 53.85 & 195 \\
\hline
\end{tabular}

Source: collected and calculated from the data of North Sinai Governorate, the Directorate of Veterinary in El-Arish, unpublished secondary data, February 2010.

Table (4). Data of farms number, productive capacity of farms and massacres in North Sinai Governorate, 2010.

\begin{tabular}{|c|c|c|c|c|c|c|}
\hline \multirow{2}{*}{ Governorate } & \multicolumn{2}{|c|}{ Farms number } & \multicolumn{2}{|c|}{ Farms capacity } & \multicolumn{2}{|c|}{ Massacres capacity } \\
\hline & Number & $\%$ & Number & $\%$ & Number & $\%$ \\
\hline Behara & 1332 & 5.13 & 567986 & 34.94 & 16080 & 9.46 \\
\hline Qaliubiya & 8000 & 30.83 & 480000 & 29.53 & 52200 & 30.69 \\
\hline Dakahlia & 2378 & 9.16 & 154823 & 9.52 & 0 & 0.00 \\
\hline Gharbia & 2965 & 11.42 & 133320 & 8.20 & 1650 & 0.97 \\
\hline sharckia & 4211 & 16.23 & 70916 & 4.36 & 26927 & 15.83 \\
\hline Damietta & 424 & 1.63 & 34827 & 2.14 & 600 & 0.35 \\
\hline Ismailia & 521 & 2.01 & 34118 & 2.10 & 15360 & 9.03 \\
\hline Giza & 1948 & 7.51 & 32053 & 1.97 & 8250 & 4.85 \\
\hline Kafr El-Sheikh & 572 & 2.2 & 31880 & 1.96 & 0 & 0.00 \\
\hline Menoufia & 643 & 2.48 & 18883 & 1.16 & 4800 & 2.82 \\
\hline Alexandria & 195 & 0.75 & 16317 & 1.00 & 6401 & 3.76 \\
\hline Fayoum & 433 & 1.67 & 11188 & 0.69 & 0 & 0.00 \\
\hline Minya & 280 & 1.08 & 10200 & 0.63 & 600 & 0.35 \\
\hline North Sinai & 246 & 0.95 & 9696 & 0.60 & 0 & 0.00 \\
\hline Qena & 163 & 0.63 & 5900 & 0.36 & 1200 & 0.71 \\
\hline Assiut & 822 & 3.17 & 5700 & 0.35 & 2100 & 1.23 \\
\hline Luxor & 167 & 0.64 & 2024 & 0.12 & 600 & 0.35 \\
\hline Suez & 67 & 0.26 & 1227 & 0.08 & 3900 & 2.29 \\
\hline Cairo & 45 & 0.17 & 1150 & 0.07 & 13200 & 7.76 \\
\hline Beni Suef & 86 & 0.33 & 1121 & 0.07 & 10800 & 6.35 \\
\hline Sohag & 304 & 1.17 & 1015 & 0.06 & 1800 & 1.06 \\
\hline Red Sea & 14 & 0.05 & 697 & 0.04 & 0 & 0.00 \\
\hline Matrouh & 46 & 0.18 & 156 & 0.01 & 0 & 0.00 \\
\hline Aswan & 42 & 0.16 & 122 & 0.01 & 0 & 0.00 \\
\hline Port Said & 21 & 0.08 & 78 & 0.00 & 3600 & 2.12 \\
\hline el wady el gaded & 18 & 0.07 & 65 & 0.00 & 0 & 0.00 \\
\hline South Sinai & 9 & 0.03 & 43 & 0.00 & 0 & 0.00 \\
\hline Total & 25952 & 100 & 1625507 & 100.00 & 170068 & 100.00 \\
\hline Damietta & 1332 & 5.13 & 567986 & 34.94 & 16080 & 9.46 \\
\hline
\end{tabular}

Source: Presidency of cabinet, Center for Information and Decision Support, the study of the economic impacts of an outbreak of bird flu in Egypt, 2010. 


\section{الآثار الإقتصادية لإنتثار مرض إنفلونزا الطيور في جمهورية مصر العربية}

عصام صبري سليمان وداليا فاروق جاب الله قسم الإقتصاد الزر اعي، مركز بحوث الصحر اءواء المطرية، القاهرة، مصر

بدراسـة الآثار الإقتصادية لمرض أنفلونزا الطيور وتداعياته على صناعة الدواجن اجن في

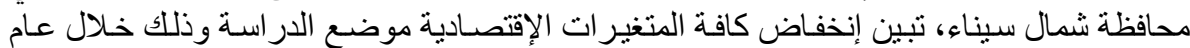

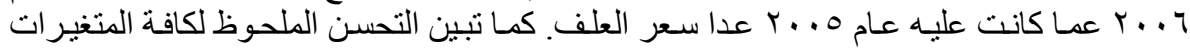

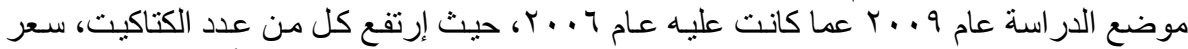

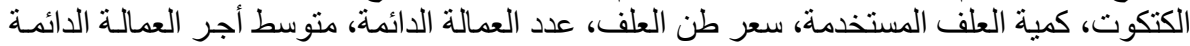

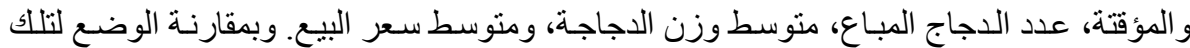

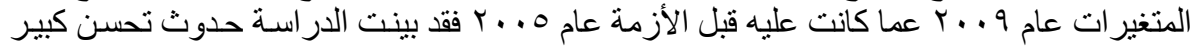

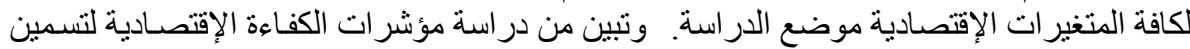

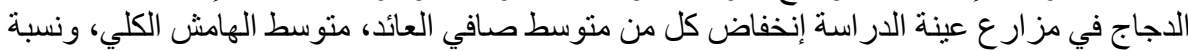

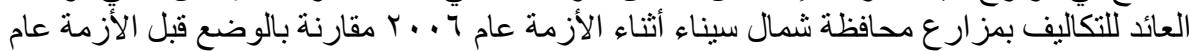

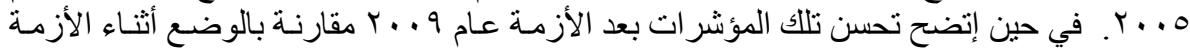

Egyptian J. Desert Res., 62/63, 71-86 (2012/2013) 
